\title{
MODERNITY AND CONSUMPTION IN NINETEENTH-CENTURY IRELAND
}

\section{Stephanie Rains}

To cite this article: Stephanie Rains (2007) MODERNITY AND CONSUMPTION IN NINETEENTH-CENTURY IRELAND, Early Popular Visual Culture, 5:3, 285-300, DOI: 10.1080/17460650701633645

To link to this article: https://doi.org/10.1080/17460650701633645

册 Published online: 26 Oct 2007.

Submit your article to this journal

Џll Article views: 306

Citing articles: 1 View citing articles $\widetilde{ }$ 


\title{
MODERNITY AND CONSUMPTION IN
}

NINETEENTH-CENTURY IRELAND:

The Araby Bazaar and 1890s popular

visual culture

\section{Stephanie Rains}

\begin{abstract}
During the 1890s, a series of large-scale, spectacular charity bazaars was held in Dublin. All of these bazaars attracted more than 80,000 visitors each, as well as extensive press coverage and a number of 'celebrity' guests. Of these, the largest and most successful, billed as 'Araby: A Grand Oriental Fete', was held in 1894 and would eventually become the basis for Joyce's short story of the same name. Araby and the other 1890s bazaars provide detailed information on the development and style of Irish popular visual culture of the fin-de-siècle. Clearly aware of their place within similar international events of the time, the bazaar organisers showed a self-conscious and competitive modernity in their programmes of events, their advertising and their visual style. In their mimicking of 1890 s consumer culture, especially that of the department store, the Dublin bazaars also highlighted the ways in which consumption had also become an embedded leisure activity within bourgeois Irish culture. This article examines the ways in which the 1890s bazaars illustrate the forms of Irish modernity during that decade, and discusses how it relates to international popular visual culture of the time.
\end{abstract}

\section{Introduction}

Throughout the 1890s, a significant number of large-scale bazaars or charity fairs were staged in Dublin. Held annually between 1892 and 1896, the largest of these were held at the Royal Dublin Showgrounds (RDS) in the middle-class suburb of Ballsbridge. All of the bazaars were fundraising events in aid of various charities, especially the Dublin hospitals, and as such, they were organised by volunteer committees and staffed by unpaid workers. In almost all cases, these volunteers and workers were middle or upper class and overwhelmingly female. In its coverage of the Araby Bazaar of 1894, for example, The Irish Times reported that it was staffed by 1,400 women. ${ }^{1}$

This article will discuss those bazaars as examples of an Irish modernity during the 1890s, which was already closely connected to international circuits of cultural consumption, new technology and popular culture. The very concept of this modernity is often contested in discussions of late nineteenth- and early twentieth-century Irish culture. The strong focus of much of this discussion upon canonical literary criticism has tended to propose an ongoing pre-modernity for Ireland during this period, even in the case of Joycean studies, which of all discussions of Irish literature are those most likely to engage with issues of consumerism and the experience of modernity. Yet much of this 
criticism specifically has denied the possibility of fin-de-siècle Dublin life exemplifying the modernity Joyce depicts in his work. Although this article is more concerned with the social history of popular visual culture than with literary criticism, it is nevertheless worth noting that critiques of work such as Joyce's story 'Araby' have received far more scholarly attention than the actual Araby Bazaar, with a resultant lack of understanding of a significant aspect of 1890 s Dublin social history. ${ }^{2}$

The first of the large-scale bazaars was the Masonic Centenary Celebration held at the RDS in May 1892. Organised by the Freemasons of Ireland, the bazaar was intended to raise money for the organisation's Female Orphan School in Dublin, and was attended by 86,914 visitors. The bazaars held in following years were not Masonic events, but were all fundraising fairs for Dublin hospitals. In May 1893, the Kosmos Bazaar was held to raise money for the City of Dublin hospital, with attendance figures of 85,457 . The following year, the Araby Bazaar, the centre of James Joyce's eponymous story in Dubliners - and the most successful of all the bazaars that decade - was held in May in aid of the Jervis Street Hospital, and attracted 92,052 visitors. In May 1895, the Ierne Bazaar was held to raise money for Sir Patrick Dun's Hospital, with an attendance of 80,000 , and the last of the consecutive fairs, Cyclopia Bazaar, was held in May of the following year to raise funds for St Mark's Ophthalmic Hospital and Molesworth Street Eye and Ear Hospital. Attendance figures for Cyclopia are not available, but contemporary reports suggest it probably attracted crowds similar to those attending Ierne the previous year. ${ }^{3}$ All of these bazaars were distinguished by their organisation around over-arching themes: the Masonic Bazaar as 'old Dublin', Kosmos was a 'world's fair', Araby was, as its name suggests, orientalist in theme, Ierne was another 'old Ireland' bazaar and Cyclopia, as a fundraising event for an eye and ear hospital, fittingly was themed around the concept of 'vision' and, to a lesser extent, 'sound'.

The first of the large-scale bazaars - the success of which was clearly the inspiration for those that followed - was held at the RDS in the Ballsbridge area of Dublin in 1892. Running from 17-21 May, the scale and ambition of the Masonic Bazaar was made clear in the extensive press coverage of the preparations for its opening, with daily reports on events throughout its duration. In its coverage of the opening day, The Irish Times commented that:

It is quite certain that no bazaar has ever been held in Dublin on a scale at once so extensive and magnificent, and it is doubtful whether any fete of a similar description has ever taken place in England or elsewhere. There is some evidence to support this — what might be called a rash statement. Messrs Womersley and Co., of Leeds, who erected ... [the bazaar stands] ... state that this is certainly the largest construct of this nature which they have ever undertaken. ${ }^{4}$

Like the future fairs it inspired, the Masonic Bazaar was organised and decorated according to an over-arching theme. In 1892, this theme was 'Old Dublin', with stalls, displays and even 'lady' stallholders' costumes designed accordingly. The official guidebook and souvenir of the bazaar stated that:

The Centenary Committee recognized at an early stage that it was necessary to have an 'Old Dublin' if their show was to be up to date. There have been Old Londons, Edinburghs, Glasgows, Manchesters, Newcastle-upon-Tyne, Belfasts. 
No Exhibition or Fancy Fair would be correct without such an institution. Probably there will be an 'Old Chicago' at the forthcoming World's Fair. ${ }^{5}$

In organising around a central theme, the bazaar organisers therefore clearly understood themselves to be operating within a broader international culture of such events, demonstrating a keen awareness of prevailing 'fashion' within public entertainments (Figure 1).

\section{Exotica and orientalism}

In keeping with the wider fin-de-siècle interests in 'the East', one of the most commonly occurring themes for decoration, costume and goods for sale at the Dublin bazaars was 'the Orient'. Broadly interpreted to include ersatz representations of everywhere from Moorish Spain to Japan, this theme emerged at different points in all of the five largescale bazaars held at the RDS during the 1890 s, but most strikingly of course at the Araby Bazaar of 1894, when the entire enterprise was operated under the over-arching theme suggested by the title.

Of course, the West's interpretation of 'the East' is evoked in the very concept of the bazaar, and this had been used both to increase the bazaar's allure to customers and to raise moral, social and political concerns about their impact upon Western society for as long as they had been held. ${ }^{6}$ Few if any moral or social concerns seem to have been raised about the 1890s Dublin bazaars, however, and indeed their presentation of 'the East' appears to have mutated by this late stage of the nineteenth century into a highly

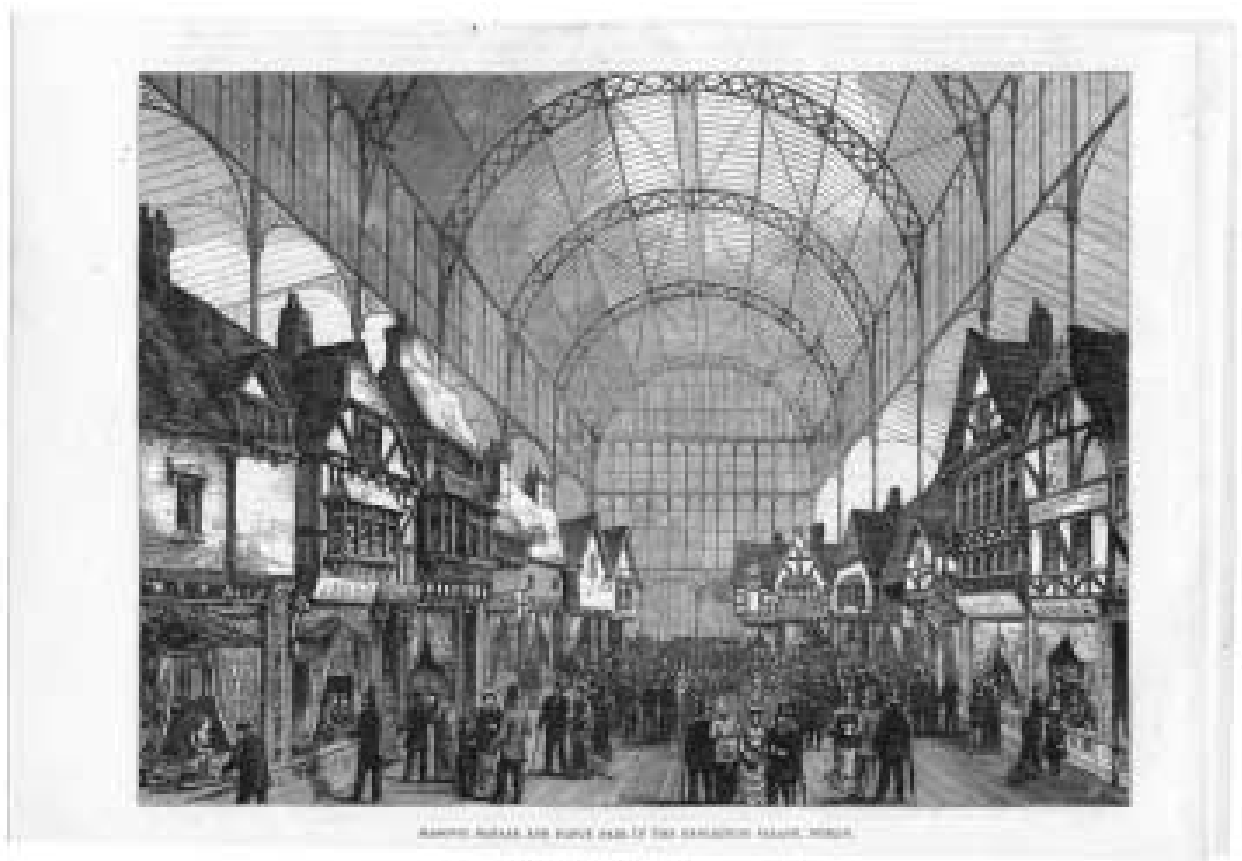

FIGURE 1 The plaster and lath 'Old Dublin' of the Masonic Bazaar, 1892. 
stylised presentation of mass-produced goods that were often merely suggestive of the 'orient'. There appears to have been a contemporary awareness of this stylisation, given that a report on the Araby Bazaar in the Dublin Evening Telegraph described the event as 'an Arab strawberry smothered in Irish cream' .

Even Araby, with its explicitly Eastern theme, not only offered oriental goods for sale, but they were the single most frequently recurring category of goods on offer; this was also true of the other bazaars that were not Eastern themed. These items ranged from 'Japanese goods' to 'Indian and Oriental Embroideries, Moorish and Egyptian Bric-a-Brac'. ${ }^{8}$ More than one of the restaurants at Araby was also Eastern themed; Sheppard's Dining Gardens served curry, which they claimed was produced by a 'Lascar' cook, ${ }^{9}$ and the Moorish Café Divan was described as being 'decorated with a series of art canopies and art fabrics, with Turkish lamps suspended. Little cosy nooks and corners, Oriental hangings, Bamboo seats, Oriental rugs and cushions, Mats and brilliant drapery, all combine to make this a charming retreat where the weary can rest and enjoy a choice Flor de Cuba or Newton in quiet repose. ... Visitors are particularly advised to taste Araby Elixir.' 10

The bazaar clearly fed into and further stimulated a consumerist and aesthetic interest in 'oriental' style among the Irish middle class. The Irish Times claimed that 'with the advent of Araby in Dublin there has been a passion for producing Arabian poetry and music', although the only example of Araby-inspired verse they printed (sung by a 9 year-old girl at a Mansion House Smoking Concert) was more explicitly consumerist than Arabian:

If you want it, come to Araby.

If you want it, come to Araby

'Tis a jolly spot

And anything you haven't got

If you want it, come to Araby. 11

Despite the artistic limitations of this verse, it does point to the crucial concept of abundance that the orientalist associations of the bazaar produced in the Western imagination. Indeed, this abundance — of goods, of people, and of spectacle and distraction - is noticeably highlighted in the bazaars' publicity and in journalistic accounts of the events.

\section{Bazaar themes}

As the first of the 1890s bazaars, the 1892 bazaar is particularly interesting for its varied tone of entertainments and spectacles, some of which were more popular with visitors than others. There is evidence from the 1892 bazaar of an attempt to provide 'serious' culture as well as popular entertainment. This may well have been due to the recognition by the organisers of the sometimes dubious reputation of bazaars, and an attempt to underscore the high 'moral tone' of their own efforts. The Masonic Bazaar contained an art gallery of paintings as well as signed photographs of Queen Victoria, most of the rest of the royal family, senior British and Irish political figures and 'men of letters' such as H. Rider Haggard, Jerome K. Jerome, Henry Irving and W. T. Stead. There was also a lecture series on such topics as a bicycling tour of Caledonia, and the African experiences 
of Surgeon Parke. ${ }^{12}$ However, these more educational or 'cultured' entertainments were notably less attractive to the public than other, more 'spectacular' diversions, and it is striking that there were no equivalents to them at future bazaars. ${ }^{13}$ The more popular entertainments included, as well as the stalls themselves: 'a Canadian circular switchback railway, serial cars, high-flying swing-boats, Mexican high-flyers' and 'a handsomely furnished tent in which a young lady representing an Indian princess will practise the interesting art of palmistry'. ${ }^{14}$

The Masonic Bazaar was an enormous popular and financial success. In its report on the closing ceremonies, The Irish Times commented that 'its success is simply unparalleled; it has beaten the record of every undertaking of a similar character in splendour, the number of attendances, and in its financial results'. The same report cited the closing speech of Lord Justice Fitzgibbon, in which he announced the bazaar had raised $£ 11,675$ 10 s $1 \mathrm{~d}$, from an attendance of 74,592 (this attendance was later revised upwards to 86,914). ${ }^{15}$ An attendance of this magnitude becomes even more striking when it is considered that according to the 1891 Census, the population of Dublin (including the unincorporated suburbs) was only $347,912 .{ }^{16}$ While it is clear that this and later bazaars attracted considerable numbers of visitors from outside the city, this nevertheless indicates that a significant proportion of Dublin's population must have attended, making the 1890s bazaars a prominent feature of popular entertainments of this decade within the city. Indeed, The Irish Times reports comment that in its initial days, the bazaar thoroughfares were so crowded that the stalls' business was impeded as potential buyers were unable to move or see the goods on display. ${ }^{17}$

\section{Costumes}

Costumes, especially for the 'lady stallholders', were central to the visual style and spectacle of the bazaars. Often linked to both the overarching theme of the bazaar and the architectural and decorative themes of the stalls, women were elaborately and often exotically costumed (Figure 2). Several contemporary commentaries note the extent to which the bazaars centre around the spectacle of the stallholders' clothing, and each year the press coverage of the bazaars focused noticeably upon the costumes associated with each stall, often describing them in some detail. It is clear from these descriptions (and surviving photographs) that these costumes were neither a simple representation of contemporary fashion nor a straightforward 'fancy-dress' event, but instead were an amalgam of the two. Thus they allowed the young women to combine an unusual level of exoticism in their dress with designs that would have marked them out as fashionable and stylish middle-class women. So while The Irish Times' reporter noted of the Araby Bazaar that the visitor found themselves surrounded by 'closely-veiled houris of the harem', photographs from the bazaar reveal young women wearing typical fashions of the 1890s, including high-necked and long-skirted gowns, albeit elaborately trimmed with 'oriental' decorations. ${ }^{18}$ It would not, of course, have been acceptable for middleclass young women to appear in the more revealingly orientalist costumes of contemporary popular culture, such as those worn by the musical hall and early cinema stars including 'Princess Raja' or 'Karina'. ${ }^{19}$ Nevertheless, the public display of middle-class girls in costumes that even remotely suggested not only the 'houris of the harem', but also popularly risqué stage entertainers of the day was clearly a considerable factor in the 


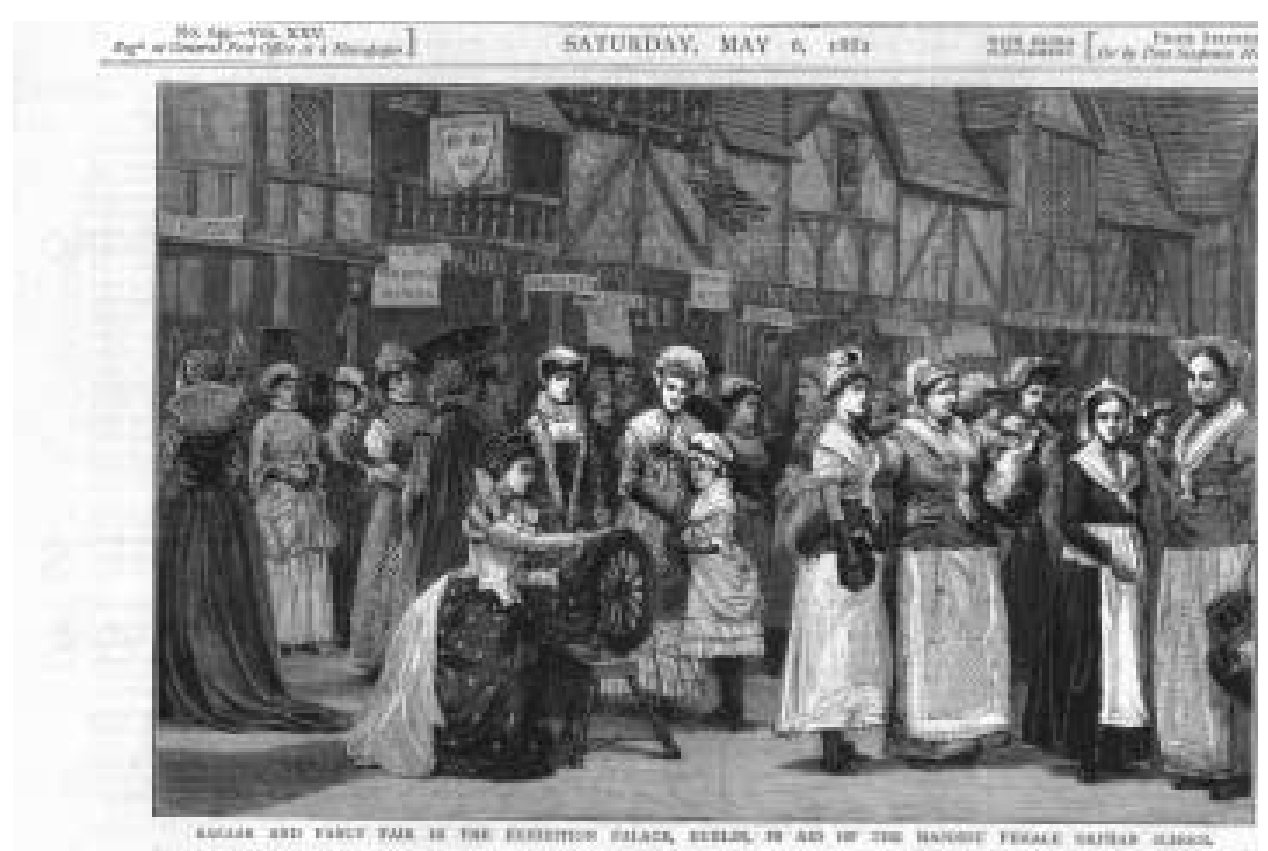

FIGURE 2 'Lady stallholders' for the 'Old Dublin' Masonic Bazaar, 1892.

bazaars' appeal, and further emphasises the familiarity of the Dublin crowds (as well as the bazaar organisers) with the 'modern' interests in both Eastern exotica and commercial entertainments such as early cinema and internationally known music hall acts.

The spectacle and exoticism of the costumes worn by the stall workers also performed an important function in linking the women to the goods they were selling. This is particularly evident in the ways in which the women's costumes, the stall decorations and the goods for sale within them were almost always linked in theme. At the Araby Bazaar, for example, the Wakayama Kwankoba Stall, with its stallholders in Japanese costumes, was selling Japanese goods, while the Hospital Founders Stall, whose workers were wearing 'Eastern trimmings', sold Indian fabrics and decorations. ${ }^{20}$ Perhaps the most striking example of identification between the 'lady stallholders' and the goods they are selling, however, is the Aladdin's Palace Stall at Araby, which sold lampshades, while the women of the stall were themselves dressed in lampshade costumes. ${ }^{21}$ This cross-theming of the luxury goods for sale and the women selling them is an explicit example of the widely discussed interconnections being made in late nineteenth-century consumer culture between female department store workers and the consumer goods they were selling. ${ }^{22}$

Women working in the various bazaar refreshment halls were also costumed. All of the Dublin bazaars of the 1890s had extensive refreshment halls, cafes, restaurants and even, in at least one instance, bars. The scale and variety of these organisations imply that they were a major contributor of funds to the bazaars' treasury, and contemporary reports suggest they were heavily patronised by visitors. These areas of the bazaars also appear to have been the only public areas where young men also volunteered alongside the women workers. The cafes and restaurants included The Café Chantant, which appeared at all the bazaars; Daly's Coffee House at the Masonic Bazaar; the Ice Restaurant 
at Kosmos; Shepperd's Dining Gardens, Café Boolàk and the Moorish Coffee Divan at Araby; and the Cead Mille Failte Tearoom at Ierne.

The women (and men) working in these establishments were, like their colleagues on the stalls, distinctively costumed. The nature of their costumes, however, points more clearly towards one of the underlying purposes of all of the costumes worn by the volunteers at the bazaars - that of impersonating real retail and service workers. The women working in the bazaars' restaurants wore costumes deliberately styled to resemble the uniforms worn by real waitresses; at the Araby Bazaar, for example, the women serving in Sheppard's Dining Gardens and Café Boolàk wore 'print dresses, muslin caps and aprons', ${ }^{23}$ while the Tea Pavilion was staffed with 'numerous ladies dressed in "waitress" costumes'. 24

This obvious mimicry of the newly widespread areas of women's work such as waitressing suggests that almost all of the upper- and middle-class young women volunteering to work at the bazaars were in fact engaging in a playful impersonation of the professional lives of working-class young women. In doing so, they were using the public display of the femininity those professional roles demanded in order to play with the boundaries of acceptable behaviour for unmarried middle-class girls and to advance their prospects within their own sphere - that of the 'marriage-market'. While serving food to the crowds at such large-scale bazaars must have been genuinely hard work for the time it lasted, it was a strikingly different experience to that of real waitresses who did such work indefinitely. Indeed, a rare criticism of the bazaars highlighted this point. In a series of investigative journalism articles entitled 'A Woman's Life in the Dublin Slums', the writer and social activist Mary Costello, commenting on the desperately needed help that charitable organisations might provide to the urban poor in Dublin, sharply criticised 'society girls' for preferring to do charity work such as that at Araby, rather than doing the harder and less glamorous work of serving in the penny restaurants that offered subsidised meals to the poorer populations of the city. ${ }^{25}$

\section{Entertainments and spectacle}

One of the most striking features of the 1890s bazaars was the range and novelty of the popular entertainments provided alongside the charity stalls. Indeed, much of the publicity surrounding the bazaars focused at least as much on the entertainments as on the stalls themselves. From the Masonic Centenary Bazaar in 1892, these entertainments had been a dramatic focal point of the bazaars, with many of them owing a considerable debt to music hall, vaudeville and funfair amusements. However, it is noticeable that many of them were also technological in nature, and indeed they appeared to become more so during the course of the 1890s bazaars.

At Kosmos and later bazaars, there were displays of skirt-dancing: a popular and originally risqué vaudeville entertainment. Particularly associated with vaudeville 'stars' such as Karina, skirt-dancing's appeal lay primarily in its revelation of the dancer's ankles and legs. However, by the 1890s, it had acquired more respectable overtones as a graceful activity that might be performed by young society ladies (the dance appears to have been modified to show less leg). Kosmos featured 'Miss Rosalie Haines, of Belfast' performing skirt-dancing, and the following year, Araby featured 'the most recent developments of the skirt dance, with novel mirror effects' (Figure 3). ${ }^{26}$ Other 


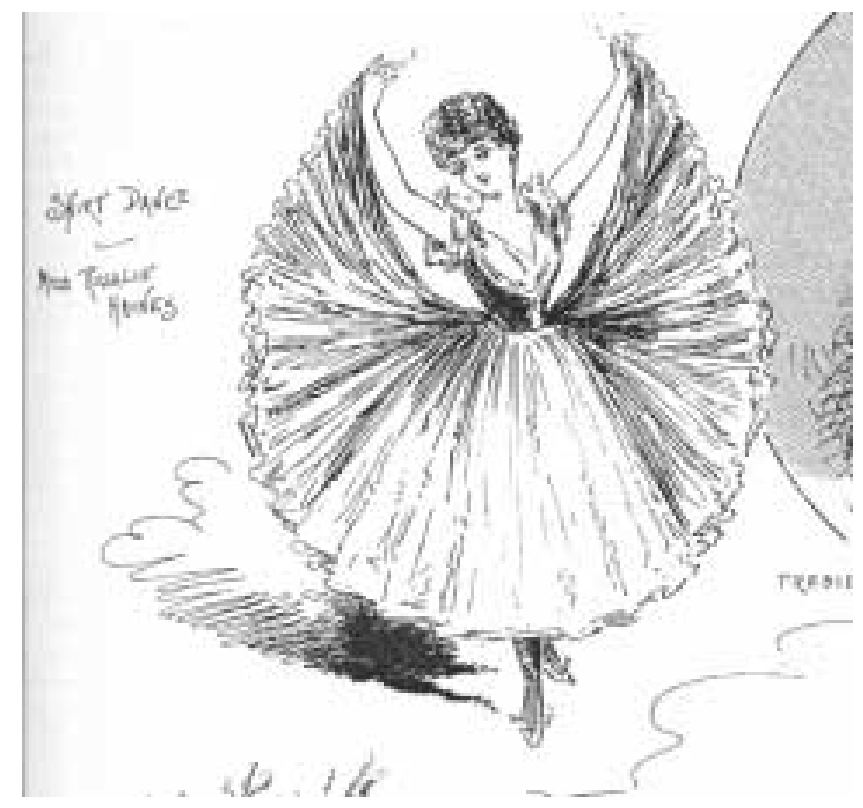

FIGURE 3 Ms Rosalie Haines' demonstration of skirt-dancing at the Kosmos Bazaar, 1893.

entertainments with obvious connections to vaudeville and funfairs included palmreading and 'Mexican high-flying' at the Masonic Bazaar, magicians, fireworks, 'Princess Nala Damajante, Hindoo Serpent Charmer' and the 'Egyptian Hall of Mystery' séance sessions at Araby. One of the other most widely advertised amusements at Araby was the appearance nightly of 'Menotti, The King of the Air, The Great Stockholm Wonder, in his Marvellous and Sensational Performance on the High Wire'. Menotti, described as Blondin's great rival, performed his evening acts by the light of the Eiffel Search Light Tower, which was also one of Araby's principal attractions (Figure 4). ${ }^{27}$

The Eiffel Search Light Tower marks the introduction to the 1890s bazaars of what might usefully be termed 'technological spectacles' - a genre of entertainment that became more prominent in each successive bazaar. The Eiffel Search Light Tower was 120 feet high and had been imported for display at Araby from the Chicago World's Fair the previous year. Described as being capable of 'turning night into day', the steel tower supported a search light of '16,000 candle-power', which was directed across the city sky and intersected with another light positioned on the roof of the Jervis Street Hospital, for which Araby was raising funds. ${ }^{28}$ This display was turned on a week before the bazaar began to function as a form of advertising on the night sky.

Other forms of 'technological spectacle' that made an appearance at Araby were the 'Alkinetic Cycles', which were in fact an early form of exercise bicycle, and nightly 'Telephone Concerts'. Run under the auspices of the Civic Stall, these were musical concerts that were effectively using the telephone as a form of radio broadcasting equipment, with each audience member listening to the distant orchestra through a telephone receiver. It was explained in the Araby brochure that: 'The National Telephone Company will give a series of Concerts each evening, when a varied selection of music will be transmitted by the 100 instruments kindly lent by the company.' 29 Given the poor sound quality this 


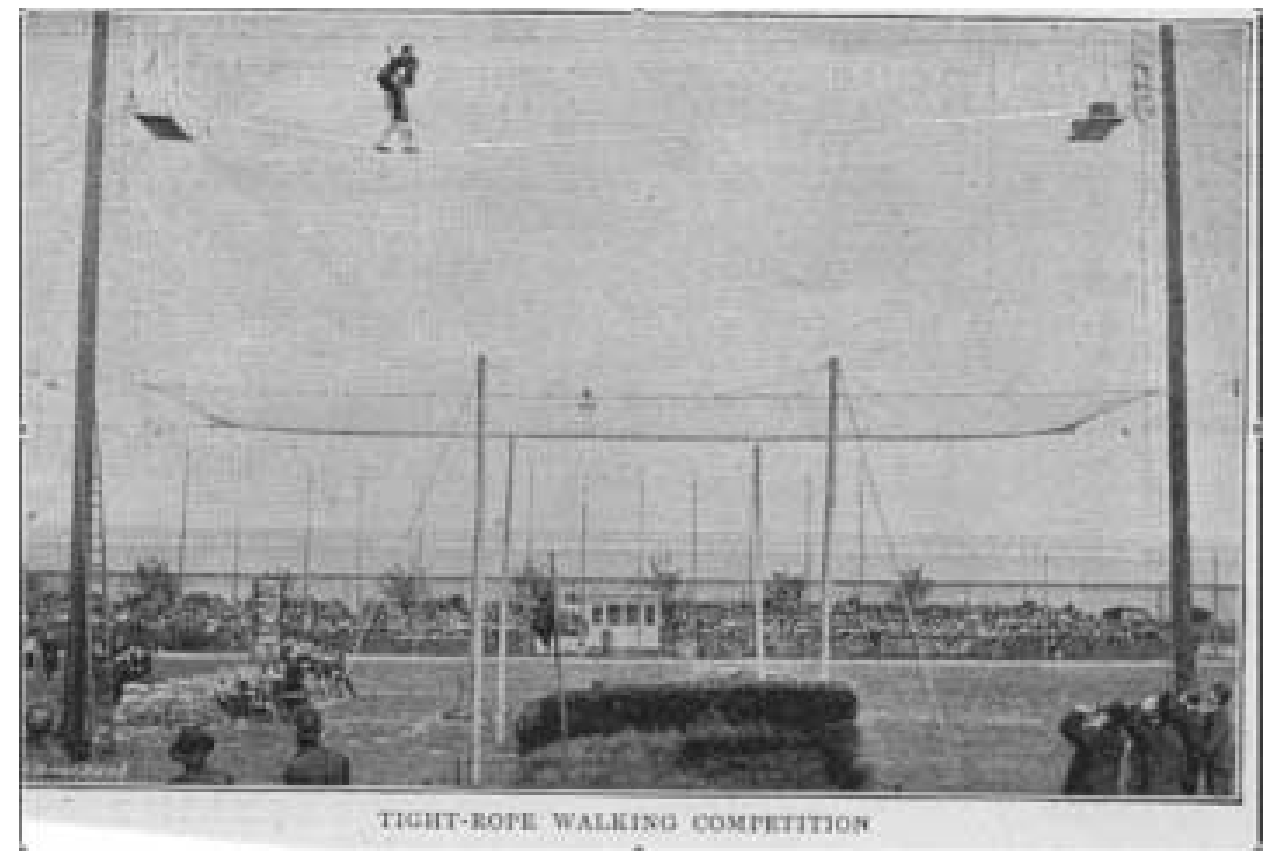

FIGURE 4 Tightrope walking competition at the Araby Bazaar, 1894.

might be supposed to have produced, it seems reasonable to conclude that the attraction of these performances, from the audience's point of view, lay in the still relative novelty of the telephone technology rather than the musical experience.

For the Ierne Bazaar of 1895, the technological spectacles offered to Dublin crowds grew in scale. Ierne featured the introduction of two particularly expensive and largescale entertainments: the Water Chute and the Captive Balloon. The Water Chute, which had made only one previous appearance at Captain Boyton's Water Show in Earl's Court, was a wooden construction, 40-50 feet high, descending into an artificial lake. A contemporary visitor to Ierne described the Chute thusly: 'There were four seats in each boat, accommodating six passengers each, with the attendant behind, and after you had been lovingly enfolded in oilskins ... you were shot down the wooden passage, railed with iron, out onto the lake, where you arrived Ixion-like, enveloped in a cloud of spray'. ${ }^{30}$ The Water Chute was very popular with the crowds at Ierne, and returned the following year for the last of the consecutive bazaars at the RDS: the Cyclopia of 1896. At Ierne, it was reported, the Water Chute 'notwithstanding the cost attendant upon its construction, cleared $£ 400$ to $£ 450$ net profit'. 31 The 'Nautilus' Captive Balloon, on the other hand, was reported to have made a slight financial loss at Ierne, although 'it afforded a magnificent advertisement to the fete' not only through its visibility at up to 1,000 feet above the RDS, but also because advertising literature for other bazaar events was thrown from the balloon onto the showgrounds below. ${ }^{32}$ Consequently, it too made a return at the Cyclopia Bazaar, although it almost certainly made a financial loss that year as well since it was reported it had 'met with an accident' on the opening day of the fete and would not be in operation again before the end of the week. ${ }^{33}$

The last of the 1890s bazaars at the RDS, Cyclopia, was most marked by technological spectacle. Held to raise money for St Mark's Ophthalmic Hospital and Molesworth 
Street Eye and Ear Hospital, it was commented by The Irish Times that: 'The committee ... have been very hard pressed to devise attractions and to contrive spectacles at once new and interesting. 34 The hard-pressed committee appear to have resolved this difficulty of providing the Dublin crowds with new and interesting spectacle by placing a particular focus upon technological marvels of the 1890s. The themes of sight and sound suggested by the institutions for which they were raising funds became the most obvious theme of the bazaar, although this was not overtly signalled in the publicity surrounding it. Demonstrating the widely discussed late nineteenth-century fascination with sight and vision, Cyclopia presented a wide range of entertainments that relied upon the latest technological developments in this area. ${ }^{35} \mathrm{~A}$ number of these entertainments were appearing in Ireland for the first time, often only very shortly after appearing in London. The Irish Times explained that:

At Cyclopia the original Animatograph will make its first appearance in Ireland. By its aid a series of 'living photographs' are thrown on a screen, and the figures of men and women in the pictures go through complete scenes. ... It is not only a marvellous invention, but also a very pretty sight, and has been for some months attracting great crowds in London. ${ }^{36}$

The 'scenes' on display via the Animatograph at Cyclopia included 'A House on Fire and Rescue', 'The Dance of the Pickaninnies' and, reportedly particularly popular with the Dublin audiences, 'The Death of Svengali' . ${ }^{37}$

Cyclopia also saw the first appearance in Ireland of Roentgen's X-Rays, which had been invented and displayed in London only a couple of months earlier. Installed in a dark-room, the new x-ray technology was presented for public entertainment and 'visitors may, if they wish, have negatives taken of the bones of their own hands by means of this marvellous discovery'. ${ }^{8}$ The Irish Times later reported that a 'surprisingly large' number of visitors had done just this, noting the Roentgen X-Ray as one of the most popular events at the bazaar. ${ }^{39}$ A locally produced entertainment showing a similar fascination with sight and vision was the Cyclopean Eye, a large mechanical eye invented by Sir H Grattan Bellew, who attended it at the bazaar in order to explain it to visitors. 'Sir Henry claims for his invention that the eye looks from side to side, up and down, winks, and in short does everything a knowing and properly conducted eye should do. ${ }^{40}$ Other attractions included a comic lantern slide show projected onto a screen 40 feet square, an astronomical telescope through which visitors could view the stars, and 'the Phonograph and its twin inventions the Kinetescope and the Kinetophone, and other high-class and scientific inventions'. ${ }^{41}$

As can be seen from this survey of attractions and entertainments provided at the Cyclopia Bazaar, there was a noticeable reliance upon the concepts of sight and, to a much lesser extent, sound. Ranging from the piercing vision of the Roentgen X-Ray to the magnifying lens of the telescope, and encompassing 'artificial eyes' such as early forms of cinema technology and even an actual mechanical eye in between, the Cyclopia Bazaar provided its visitors with a full range of late nineteenth-century scopic technologies.

In sum, the entertainments and attractions offered by the five 1890 s bazaars held at the RDS indicate not only a considerable market in Ireland for large-scale and spectacular amusements, but also an awareness and sense of interconnectedness with the international technological developments that were making them possible. As was discussed 
above, both the content of the bazaars and the tone in which they were reported is suggestive of a sense of local and national pride at the scale and modernity of the bazaars. The organising committees (and therefore, it may be concluded, the wider public as well) were demonstrating a keen awareness of the cultures of consumption available not only in London, but also in the United States, and were enthusiastically embracing the spectacle, distraction and excitement they offered.

\section{Charity and enterprise}

The grand-scale bazaars of the 1890s in Dublin can of course be read as an important contribution to philanthropic work of the time. With each bazaar raising a typical sum of $£ 10,000$ each year, their contributions to the causes they supported were considerable. Most of the bazaars were fundraising events for the Dublin hospitals, and as such they need to be understood as important forerunners to the more widely known methods of healthcare fundraising of the early and mid-twentieth century in Ireland, such as the Hospital Sweepstakes used during the early years of Independence. ${ }^{42}$ One final but important aspect of the 1890s Dublin bazaars that must be considered, however, is their role within the economy of the city. Given their scale and duration throughout half of the decade, their contribution, both directly and indirectly, to economic activity within Dublin must be regarded as significant. With more than 80,000 visitors attending each bazaar, these were sizeable economic as well as social or philanthropic events, even though the profits were being donated to charitable causes.

As briefly discussed above, charity bazaars of the late nineteenth century moved away from the traditional practice of offering goods mainly produced by the women working on the stalls. It is clear that the 1890s bazaars in Dublin were selling large quantities of mass-produced goods, both Irish-made and imported via Britain. As well as the stall goods themselves, other crucial activities within the bazaars would also have relied upon wholesale supplies of goods and services, most of them provided by the business communities of Dublin. With cafes and restaurants capable of seating up to 1,000 visitors at a time (and reported as doing a brisk trade), the food and drink supplies alone to the bazaars must have been considerable. Some of the newspaper advertisements for Araby were produced in conjunction with businesses who were supplying such refreshments, including one advertising 'Club Kola', a 'sparkling, non-alcoholic beverage' made by Cantrell and Cochrane, which was sold at all the bazaar refreshment stalls. ${ }^{43}$

The strong emphasis upon costumes for the hundreds of 'lady stallholders' would also have stimulated trade for drapers, milliners and department stores in Dublin and beyond. Evidence suggests that the elaborate and extensive stalls, stands and background scenery was largely provided by specialist companies from England, but the 'dressing' of these stalls, restaurants and displays is more likely to have been locally provided. In 1895, for example, it was reported that 'Messrs Dods \& Buchanan, of Grafton Street, Dublin, have supplied no fewer than 270 hats for lady stallholders at the Ierne Bazaar' 44

The 1890s bazaars have a number of cultural connections to the department stores of the era in terms of spectacle, conspicuous consumption, and an emphasis upon distraction and playfulness. However, they also appear to have had more tangible connections to such businesses: among others, through their wholesale purchase of goods for sale at 
the bazaars. It might be supposed that the department stores, milliners, fancy good shops, restaurants and draper's warehouses would have regarded the bazaars as unwelcome competition, given that they were offering essentially the same goods, services and experience to visitors. There is evidence, however, of a symbiotic relationship between such businesses and the bazaars - one that may well have been of crucial economic importance to both sides. It is clear that a number of businesses in the city donated or loaned goods to the bazaars as this is mentioned in the publicity for a number of bazaars and was probably highlighted at the bazaars themselves. In the coverage of the Araby Bazaar of 1894, for example, a list of the merchants who donated refreshments for the cafes and restaurants appeared in the advance publicity. ${ }^{45}$ Following the Ierne Bazaar the next year, The Lady of the House magazine commented that: 'It is only right to mention that all the very pretty table glass used in the "Ierne" Dining Room was most kindly lent by Messrs Whyte \& Son, South Great George's Street, Dublin. ${ }^{46}$ Other businesses in the city offered preferential rates to those connected to the bazaar. For example, prior to Araby, advertisements appeared announcing that the Hibernian and Shelbourne hotels would offer special one-week packages to country visitors attending the bazaar. ${ }^{47}$

The drapers, department stores and fancy goods shops whose stock mirrored the goods on sale at the bazaar stalls also appear to have seen a commercial advantage to the bazaars, both through the wholesale trade of goods for sale and the increased number of visitors to the city who might combine a visit to the bazaar with a shopping trip to the city centre. Prior to the beginning of the Masonic Centenary Celebration of 1892, Pim Brothers Department Store in South Great George's Street, Dublin were advertising in the national press that they had 'arranged a Special Department for the Sale of Fancy Goods, Suitable for the Bazaar. Purchasers will be enabled to Select Goods at Special Prices, which will enable them to be re-sold on favourable terms. ${ }^{48}$ Two years later, during the preparations for the Araby Bazaar of 1894, Pims were continuing to supply bazaar traders, announcing that due to the demand created by Araby, its 'Liberty Department' had now received extra stocks of 'eastern carpets, Japanese screens and Oriental knick-knacks' ${ }^{49}$ In the month before the 1895 Ierne Bazaar, Moneypeny's Art Needlework House of 52 Grafton Street, Dublin, was advising that: 'Successful Bazaar Stallholders should lose no time in securing, at Moneypeny's, Laundry Bags, white, at $61 / 2 \mathrm{~d}$ and $91 / 2 \mathrm{~d}$ each; 5 o'clock Tea Covers, 11d, 1/4, 2/ - each.' 50

That retailers anticipated a boost to local trade created by both the atmosphere and the tourists visiting Dublin for the bazaars is clear from other advertisements that appeared each bazaar 'season', such as that published by the Henry Street Warehouse. One of the largest department stores in the city, in May 1895 it advertised that 'Ladies visiting the Bazaar are invited to inspect the magnificent display of French fashions which will be exhibited day by day in our new windows and warerooms. ${ }^{51}$ The general increase in trade and commerce within Dublin created by the scale of the bazaars is indicated by an approving comment in The Lady of the House upon the practice of charity bazaars:

To alleviate the sufferings of the indigent through the amusements of the more happily circumstanced and, at the same time, to give a considerable impetus to the trade of a great city, by attracting to it the wealthy votaries of fashion, are achievements of which any persons may well be proud and these the spirited projectors of 'Kosmos' will, we believe, be found to have successfully accomplished. ${ }^{52}$ 


\section{Conclusion}

The fact of Dublin's late nineteenth-century modernity, however, proved controversial to a number of critics, even those of that era. Yeats' objections to the culture of the Dublin bourgeoisie was based primarily upon their means of gaining wealth through their (for him) too close connections to the 'greasy till' of commerce. ${ }^{53}$ Given his further objections to the appearance of neon advertising signs on O'Connell Street, however, it is clear that he was no happier with their culture of spending wealth and indeed saw it as a genuine and immediate threat to Irish identity. ${ }^{54}$ More contemporary critics, especially those assessing the work of James Joyce, the writer most obviously aware of the 1890s bazaars, have also addressed the issue of Dublin's 'modernity'. Where Yeats expressed horror at the signs of modernity and commodification in Ireland during this time, for many critics of Joyce's modernism, the extent to which early twentieth-century Dublin was participating in the wider experiences of modernity as represented across the rest of Europe has continually been challenged.

It is often argued that 'Joyce's Dublin' as represented particularly in Ulysses and Dubliners was not in fact the 'real' Dublin. Critics frequently maintain the impossibility of fin-de-siècle Dublin standing as the quintessential modernist milieu as might Paris or Berlin because of the image of 'backwardness' and lack of engagement with wider European and therefore 'modern' issues that Ireland was seen to be locked into at the time. As Franco Moretti argues, 'if the city of Ulysses were the real Dublin of the turn of the century, it would not be the literary image par excellence of the modern metropolis' ${ }^{55}$ This argument positions Dublin in the early twentieth century as being inherently precluded from a 'genuine' experience of European modernity, and as being instead a cultural and economic backwater on the margins of the mainstream experience.

Writing in specific assessment of Gerty MacDowell's relationship to commodification in Ulysses, Thomas Richards argues that due to Dublin's lack of modernity, MacDowell is 'off balance and curiously vulnerable' in her imaginative connection to advertising and commodities. Richards insists that the city did not compare to other Western capitals in terms of advertising spectacle and other cultures of consumption. Instead, he argues that in Dublin:

[L]life remained much more provincial, much more old-fashioned, much less contemporary than in the Paris of Zola or the London of Gissing. No wonder that Irish writers took so long to discover the commodity. Even after 1904 a consciousness of modern life was slow in awakening. ... In his grasp of the extent to which Ireland had become so materially modern while remaining immersed in traditional attitudes and institutions, Joyce stands alone in Irish literary history. ${ }^{56}$

Richards here appears to acknowledge Dublin as 'materially modern' while at the same time denying its impact or meaning within Irish culture of the time. He also does not discuss Joyce's 'Araby' as another example of the writer's engagement with commodity culture. Other critics have examined 'Araby' within this context and yet their conclusions frequently suggest a refusal to accept consumption and commodification as acceptable or 'authentic' within an Irish context. Donald T. Torchiana, for example, is one of the few Joycean critics to have examined 'Araby' using the historical framework 
of the actual event. Undermining Richards' assertions about the lack of an immersive advertising culture in Dublin, Torchiana records that:

For months plain posters had adorned all Dublin featuring the word 'Araby' in brown letters on a yellow background - the two colors of the story's first page. Most stores also had photographs or cards signaling the coming bazaar. In fact promotions extended to the entire British Isles with most railways advertising Whitsuntide excursions heading their bills with the notice 'Araby in Dublin'. ${ }^{57}$

After describing some of the style and nature of the Araby Bazaar's events, however, Torchiana emphatically rejects them as acceptable cultural practices. He asserts: 'If none of these vulgar particulars lodged in Joyce's mind, I nevertheless submit that the generally trite, overblown carnival atmosphere of the charity bazaar, however worthy, is no small part of the boy's pained recognition at the story's end.' 58

Later critics have suggested that Joyce had an enthusiastic, if typically acerbic, appreciation of popular and 'vulgar' cultural practices. ${ }^{59}$ The actual historical framework of 'Araby', however, has continued to be neglected and the eponymous bazaar is not recognised as being either the sizeable event it was, or as revealing of those popular and fundamentally modern cultural practices so decried by those for whom they can never be authentically Irish.

\section{Notes on contributor}

Stephanie Rains is lecturer in Media Studies at the National University of Ireland, Maynooth. Her book The Irish-American in Popular Culture, 1945-2000, was recently published by Irish Academic Press.

\section{Notes and references}

1. Dublin Evening Telegraph, 16 May 1894, p. 2.

2. Joyce, J. (1992) 'Araby', in Dubliners, Wordsworth Classics, London.

3. The Lady of the House, June 1894, p. 6; June 1896 p. 2.

4. Irish Times, 18 May 1892, p. 5.

5. Grand Centenary Celebration, Dublin May 17 to 21 1892, Book of the Centenary, including the Official Catalogue, Dublin, p. 189.

6. Dyer, G. R. (1991) "The "vanity fair” of nineteenth-century England: Commerce, women and the East in the ladies' bazaar', Nineteenth Century Literature, vol. 46 no. 2, p. 197.

7. Dublin Evening Telegraph, 19 May 1894, p. 8.

8. Anon. (1984) Araby in Dublin Official Catalogue, p. 31.

9. Irish Times, 18 May 1894, p. 6.

10. Anon. Araby in Dublin, p. 35.

11. Irish Times, 18 May 1894, p. 6.

12. Irish Times, 11 May 1892, p. 5; 19 May 1892, p. 5.

13. Irish Times, 21 May 1892, p. 5. 
14. Irish Times, 16 May 1892, p. 5.

15. Irish Times, 23 May 1892, p. 5; The Lady of the House, June 1894, p. 6.

16. Daly, M. E. (1985) Dublin the Deposed Capital: A Social and Economic History, 18601914, Cork University Press, Cork, p. 3.

17. Irish Times, 18 May 1892, p. 5.

18. Irish Times, 16 May 1894, p. 6.

19. The connections between the orientalism of much of the bazaars, and the 'oriental' styling of many contemporary popular acts such as 'Princess Raja' or 'Karina' is particularly significant given that the 1890s bazaars were the showcases for many new kinds of cinema technology (see Mullin, K. (2003) James Joyce, Sexuality and Social Purity, Cambridge University Press, Cambridge, pp. 140-170).

20. The Lady of the House, May 1894, p. 6.

21. The Lady of the House, May 1894, p. 6.

22. The most common theme of these concerns was the fear that women shop-workers supplemented their low incomes by accepting 'gifts' from male admirers, including male customers of the shops they worked in, thus having been 'bought' like one of the commodities in the stores. One of the most famous accounts of this supposed phenomenon was W. T. Stead's 1894 publication, If Christ Came to Chicago, which includes an 'exposé' of department store workers' lives, and in which he claimed that 'not food but clothes, not plain clothes but finery, that is ... the want that drives many to a life of shame' (cited in Lanchester, B. (2000) The Department Store: A Social History, Leicester University Press, Leicester, p. 179). Modern critics have pointed out that there is actually very little evidence for these claims, but this does not diminish the extent to which they constituted a widely circulated moral panic in the late nineteenth century. It therefore casts an interesting light on the use of volunteer work at the charitable bazaars as a display of eligible upper-class girls for the Dublin marriage market, not to mention Stead's own contribution of a signed photograph to the 1892 bazaar, as mentioned above (see Miller, M. (1981) The Bon Marché: Bourgeois Culture and the Department Store, 1869-1920, Allen \& Unwin, London, pp. 192-197; Lanchester, The Department Store, pp. 178-184).

23. Anon. Araby in Dublin, p. 55.

24. The Lady of the House, May 1894, p. 6.

25. The Lady of the House, April 1896, p. 6.

26. The Lady of the House, May 1894, p. 8.

27. Anon. Araby in Dublin, pp. 57, 65, 75.

28. Anon. Araby in Dublin, p. 73; Also reported in Irish Times, 9 May 1894, pp. 3-4.

29. Anon. Araby in Dublin, pp. 57.

30. The Lady of the House, June 1895, p. 7.

31. The Lady of the House, June 1895, p. 2.

32. The Lady of the House, June 1895, pp. 2-7.

33. Irish Times, 21 May 1896, p. 5.

34. Irish Times, 19 May 1896, p. 7.

35. Many critics have analysed the nineteenth-century fascination with vision. Kate Flint, commenting upon the development of visual technologies, has argued that: 'These instruments, together with the marvels of scale produced by the telescope and the increasingly domesticated microscope, served to challenge, at the level of popular perception, the quality of observations made by the unaided human eye' (see Flint, K. (2000) The Victorians and the Visual Imagination, Cambridge University Press, Cambridge, p. 5). 
36. Irish Times, 15 May 1896, p. 5. The Animatograph, formerly known as the Theatograph, had been invented by Robert Paul, and first exhibited at The Alhambra in London on 25 March 1896.

37. Svengali, of course, appears in George Du Maurier's novel Trilby, which was published in 1894 and was one of the popular cultural sensations of the decade. It is possible that Dublin audiences were especially appreciative of the Animatograph of 'The Death of Svengali' at least in part because the novel's eponymous heroine is Irish (see Daly, N. (2005) 'The woman in white: Hiffernan, Courbet, Du Maurier', Modernism/Modernity, vol. 12, no. 1, pp. 1-25.

38. Irish Times, 15 May 1896, p. 5.

39. Irish Times, 21 May 1896, p. 5.

40. Irish Times, 15 May 1896, p. 5.

41. Irish Times, 19 May 1896, p. 7. While the Phonograph had been invented in 1877, the Kinetescope first appeared in viewing parlours in 1894, and the Kinetophone, which synchronised sound with the images on the Kinetescope, appeared in spring 1895, one year before the Cyclopia Bazaar.

42. Colman, M. (2002) 'The origins of the Irish Hospitals' Sweepstake', Irish Economic and Social History, vol. 29, pp. 40-55.

43. See Dublin Evening Mail, 19 May 1894, p. 2.

44. The Lady of the House, May 1895, p. 2.

45. The Lady of the House, February 1894, p. 8.

46. The Lady of the House, June 1895, p. 2.

47. The Lady of the House, February 1894, p. 8.

48. Irish Times, 11 May 1892, p. 4.

49. Irish Times, 9 May 1894, p. 4.

50. The Lady of the House, April 1895, p. 4.

51. Irish Times, 24 May 1895, p. 8.

52. The Lady of the House, May 1893, p. 19.

53. Yeats, W. B. (1989) 'September 1913', in Yeats's Poems, ed. A. N. Jeffares, Gill \& Macmillan, Dublin, p. 210.

54. Gibbon, L. (1996) Transformations in Irish Culture, Cork University Press, Cork, p. 165.

55. Moretti, F. (1983) Signs Taken for Wonders, Verso, London, p. 190.

56. Richards, T. (1990) The Commodity Culture of Victorian England: Advertising and Spectacle, 1851-1914, Stanford University Press, Palo Alto, CA, pp. 239-240.

57. Torchiana, D. T. (1986) Background for Joyce's Dubliners, Allen \& Unwin, London, p. 56.

58. Torchiana, Background for Joyce's Dubliners, p. 60.

59. See Leonard, G. (1998) Advertising and Commodity Culture in Joyce, University Press of Florida, Gainesville, FL; Mullin, James Joyce; Wicke, J. (1988) 'Advertising Fictions': Literature, Advertisement and Social Reading, Columbia University Press, New York. 